\title{
The Social Criticism in 2021 Sundanese Folk Song before the Era of Industrial Revolution 4.0
}

\author{
Darsita Suparno ${ }^{1}$, Yani'ah Wardhani ${ }^{2}$, Muhammad Wildan ${ }^{3}$, Aqidatul Izzah Chairul ${ }^{4}$ \\ \{darsitasuparno@uinjkt.ac.id ${ }^{1}$, yani'ah.wardhani@uinjkt.ac.id², dosen00279@unpam.ac.id², \\ aqidatul.izzahc19@mhs.uinjkt.ac.id ${ }^{4}$ \} \\ UIN Syarif Hidayatullah Jakarta ${ }^{1,2}$, Universitas Pamulang ${ }^{3}$, UIN Syarif Hidayatullah \\ Jakarta $^{4}$
}

\begin{abstract}
The use of Sundanese in folk songs can be a tool to strengthen the integrity of the nation, recognize social identity, thoughts, and culture. Unfortunately, Sundanese folk songs have not been used as a reference by the community to determine their civilization. This study aims to figure out the use of Sundanese language that expresses social criticism in various activities in society. The data were analyzed using the theory of the Hymes SPEAKING model. The results show these folk song lyrics contain forms of social criticism, namely, social values, social politeness, physical behavior patterns, and social interaction. A cyber-pragmatic perspective has used in this study found seven types of social criticism: the influence of foreign cultures, social distance, social status, social interaction using internet-connected gadgets, and vertical relationships between individuals.
\end{abstract}

Keywords: Sundanese songs; social criticism; cyber-pragmatics; context; Youtube

\section{Introduction}

Social media is one element of internet-based information technology that emerged at the end of the 19th century. It changes the way the world communicates. Cell phone with internet access becomes important and inseparable device in people's life to get acquainted with it. Everyone is very dependent on social media to support their activities, not to mention Sundanese people. Since the Corona Virus outbreak that began in the end of 2019, millions of Sundanese people have relied on social media to communicate, find information and enjoy entertainment. Based on this study's observation, Indonesia in general and Sundanese's society, in particular has started using social media extensively since the Covid-19 outbreak of this deadly virus emerged in early March 2020. The Covid-19 pandemic has changed the offline learning process to online learning. [1] Whereas before the outbreak occurred, the use of social media must refer to the regulation of the Ministry of Communication and Information, which proposes that the age limit for having a social media account is 17 years. [2], [3].

In other words, in the era of the COVID-19 pandemic, the process of teaching and learning, accessing entertainment, and exchanging information have changed. The electronic 
learning system makes it easier for students to learn without direct interaction. The presence of a smartphone for every student is crucial to support the learning process. It calls the necessity for the implementation of the learning system. [1], [4], [5], [6]. In addition to teaching and learning, the use of social media among Sundanese people from all social levels is a necessity. Meanwhile, every day people access social media for various needs such as finding information, doing business, work, entertainment, buying, and selling online. In short, the number of internet-based social media users is increasing as shown in the news in Kompas.com November 9th, 2020 edition entitled 'Indonesian Internet Users until the Second Quarter of 2020 reached 196.7 Million People. This news explained that in 2018, the number of internet users in Indonesia was only 171.2 million people, then it increased in 2020 to 196.7 million people. [7], [8], [9]. In short, media social users, community members, either individually or in groups, can become producers on social networks to produce something. They can be write, make spoken speech, photos on Instagram, and even can deliver many songs, with the nuances of social criticism lyrics. Social criticism refers to communication in a society that aims or functions as the control throughout a social system.

This study focuses on the Sundanese, especially, the use of Sundanese in Sundanese pop song lyrics as the object of research. This community is known as the singing community. Much of the song's content has the nuances of social criticism. It is reflected in Sundanese song lyrics. Indeed, from a linguistic perspective, this fact is interesting. Of course, Sundanese songs with the nuances of social criticism use language, but the problem is why the meaning of the song lyrics has a 'hidden' meaning to express criticism. Anyhow, criticism is needed for life to pour or express what is unexpressed in the heart. [10] Freedom to express criticism can be referred to the legal basis in Indonesia, which explains that every citizen is free to express his opinion, by the protection of Article 1 paragraph 1 and 2 of Law no. 9 of 1998 concerning the Freedom of Expressing Opinions in Public [11], [12], [13].

Referring to this basic rule of law's, social criticism can be delivered in various ways and forms. One of them uses social media, in the form of sound art media, such as songs. The sound art media itself has long been used as a medium to deliver criticism in the form of satire from an artist to the community at large. In this study, song lyrics are considered as short poems that express emotions, experiences, feelings, and thoughts. These lyric have been interpreted as a sung poem. It is arranged in a simple arrangement and expresses something simple as well. [14] The social reality displayed by the artist through the lyrics of the song in his work can change the values of the listener's life. In general, it is not easy to instantly understand the meaning of social criticism that appears in the media of music, art, and literature. It is interesting for this researcher to examine the phenomenon using a pragmatic approach to the lyrics of Sundanese pop songs, which contain the meaning of social criticism. The study is not from a general pragmatic dimension and not from a culture-specific pragmatics perspective, but a cyber-pragmatics perspective.[15]

\subsection{Questions of the Study}

This study attempts to find answers for the following question: a) how is the form and meaning of constative and performative utterance of the lyrics that contain social criticism?; b) What are the motives of social media users in conveying social criticism through Sundanese's folk-songs?

\subsection{The Purposes of this study}


This study aim is to describe the form and meaning of pragmatics of social criticism in Sundanese pop song lyrics from a cyber-pragmatics perspective. The goals of analyzing the form and meaning of constative and performative utterance of the lyrics that contains social criticism in the Sundanese folk-songs are: a) to describe the form and meaning of constative and performative utterance of the lyrics that contains social criticism; b) to generate the motives of social media users in conveying social criticism through Sundanese's folk-songs.

\subsection{The Significance of this Study}

The function of this study are: 1) for the writer to improve the writer's knowledge and skill in analyzing song lyric based on cyber-pragmatics point of view, and to enhance the writer's knowledge in interpreting the meaning of Sundanese's folk-song lyrics; 2) for the reader to give information and improve knowledge of Sundanese's folk-song lyrics, and to add information of the illustration of Sundanese's folk song lyrics; 3) to be a reference for other researchers who want to analyze cyber-pragmatics subject regarding folk-song verbal text.

\subsection{Related Study, Review of Literature, the Theoretical Framework}

\subsubsection{Related study}

Over the last few years, the existence of cyber-pragmatics influences stimulates scholars to conduct social media studies such as You-tube services and social networking sites that are shifted the way people interact online and search for information, opinions and entertainment. There has been a consensus among them that conducting studies would investigate the nature of the impact of against internet the use of language and tackle any causes for possible communication breakdowns across speakers of different linguistic backgrounds such as: the internet and social media have made the spread of these hateful messages easier, quicker and more impactful. [16], [17], [18], [19]. Some scholars dedicate their studies to folk songs as a case study to show that the composer's role is of prime importance in producing folk songs and the content of social critics. The arranger performs a very different function from the arranger in other types of folks song music such as featured arrangements of older songs in new formats. For example, female vocalist Nji Mené popularized the Sundanese-language song "Sorban Palid" (Turban flowing on the river), composed by R. Wirasasmita in the early1930s. [20], [21].

There are some similarities between the four related studies above and this study namely to describe pragmatics studies concerning the form of social critics that is contained in the folk songs. The differences of this research from the previous findings above were related to the object of the research and the theory used by them. Specifically, the object study of Perano and Park's research is actually the same but only different in object material. Park's object of study was the role of social norms in the context of entertainment media selection (2020), and Perano's object of study was metacritic's scoring of movie critics.' Metacritic refers to a website that collects reviews of films, TV shows, music albums, video games and formerly, books (2021). Next, the object study of Ridwan and Susanti's research is actually the same but only different in object material Ridwan's object of study was the arranger in pop Sunda, Sundanese popular music of west Java, Indonesia and Susanti's humanity and social critics in the lyrics of Iwan Fals's songs. Among the four studies Perano (2021) describes reviews of entertainment products in the text and context of film whereas Park (2020) identified whether the role of social norms in the context of entertainment media selection is based on social 
identity theory or the theory of normative social behavior. Different from those researches, this present study analyzes social criticism contained in the lyrics of Sundanese regional pop songs.

\subsubsection{Literature Review}

\section{a) Pragmatics}

Pragmatics refers to the linguistics that studies the language used with the form and meaning associated with the speaker's intent, context, and circumstances. [22] Pragmatics is the study of "invisible" meaning, or how we recognize what is meant even when it isn't actually said or written. [22] Based on this definition, it is concluded that pragmatics is a branch of linguistics that studies the aspects of the intention behind the speech of a speaker or writer, which examines the interrelationships between functions, speech forms, or texts. As this pragmatics study makes virtual external context of the lyric of the song in social media, this section is dedicated to apply cyber-pragmatics as the frame of reference. Sundanese songs, which uses Sundanese as a medium of communication are present on social media such as You-tube and becomes the ground for pragmatic analysis in cyber-pragmatics. Various kinds of song lyrics with the nuances of social criticism are easy to find on social media. It seems to be a field of cyber pragmatic analysis.

\section{b) Cyber-Pragmatics}

As this pragmatics study makes virtual external context of the lyric of the song in social media, this section is dedicated to apply cyber-pragmatics as the frame of reference.

\section{c) Context}

According to Hymes, in speech events, several factors mark the existence of the event, the initial phoneme configuration of these eight factors forms the word SPEAKING, namely. a) The setting or scene is the place and atmosphere of the speech event; b) participant, namely the speaker, speech interlocutor, or other party; c) end or destination; d) act, which is the action taken by the speaker in the speech event; e) key, namely the tone of voice and the variety of language used in expressing speech and the characteristics of expressing it; f) instrument, namely tools or writing, by telephone or face to face; g) norms or norms, namely rules that must be obeyed by each participant of the speech; h) genre, i.e. type of activity, [23]

\section{d) Speech Act}

Speech act is a condition when someone says something, then that person must also do something. [24] The action performed by producing an utterance will contain three interrelated speech acts, namely: locutionary acts, illocutionary acts, and perlocutionary acts. [24] Speech act is the type of action performed by a speaker with the utterance to describe actions such as requesting, commanding or informing. [25] In brief, speech act refers to the action performed by a speaker with the utterance.

\section{e) Social Criticism}


Social criticism is a form of communication in society that aims or functions as a control throughout a social system or social process [26], [27]. The emphasis in this sense is control over a social system or social process which is a social reality. Social criticism is the expression of a reasoned opinion on something that includes judgment, truth, or putting things by reality (righteousness). [28] In short, social criticism is a form of communication in the form of opinions, on a behavior that occurs in society related to social processes. Social criticism has a role as an attempt to maintain social balance.

\section{f) Social Media: YouTube}

YouTube is a video sharing website. In this web, YouTube users can upload, watch and share videos. [29], [30]. YouTube is a social phenomenon, a social media practice where people post videos. The narrative that is built around YouTube depends on who creates the text, a pragmatic goal. [31] In short, YouTube is a website for various streaming videos that are used by social media users to market products in the online world with gadgets and internet connections.

\section{g) Music}

Music is a creative work in the form of sound or sound that has tone, rhythm and harmony. [32] Music that is played into an integrated and continuous composition can influence emotions and cognition. [32] Music cannot be separated from human life. Every day people listen to music. Music is a universal language, the chanting of tones and musical styles in playing music becomes its language to convey moral messages, love, social criticism and others. Humans love to sing and play music. Music is universal. Music is a part of human life because humans have creativity, taste, and intention. This response also encourages people to be creative in creating music in the form of songs, sounds and sounds.

\section{h) Song Lyrics}

Song lyrics as one of the building blocks in songs or music is categorized as poetry in literary works. [21, p. 4]. Song lyrics are a literary premise and, more specifically, poetry [33, p. 143]. Thus, song lyrics fulfill a new set of functions for listeners. Engagement with lyrics has impressed when fans of folk and pop songs can place their tastes alongside the 'higher' cultural values embodied in the song's lyrics [33, p. 143]

\subsubsection{Theoretical Framework}

To analyze the form and meaning of the Sundanese folk-song lyrics that contain social criticism, Austin's theory of sentences concept (1962) is used. In addition, the concept of the performative sentence (1962) is used to analyze sentences that can form or create actions. According to Francisco Yus's virtual community concept is used to generate the motive of social media users in conveying social criticism through folk songs. [15]

\section{Method}

\subsection{Approach of the Study}


The writers use the qualitative approach to analyze: the form and meaning of constative and performative utterance of the lyrics that contains social criticism which are shown the motives of social media users in conveying social criticism through Sundanese's folk-songs. It means that data are verbal and its contexts used by the author of the song collected by reading the text lyric and listening to the song, and these data are part of qualitative data as they are in sentences and word forms. Besides that, they are identified based on the concept of constative and performative utterance as one of the phenomena that occur in virtual communication. Creswell defined qualitative research as an attempt to ensure that data and analysis will closely reflect what is happening. Qualitative research is a form of interpretive inquiry in which researchers make an interpretation of what they see, hear, and understand. Their interpretations cannot be separated from their own backgrounds, history, contexts, and prior understandings [34]. It is also concerned with how people think and act in their everyday lives.

Referring to the constative and performative utterance examined in with the theme of 'social critic' and as social criticism and humanity, this research is classified into descriptive research. The term descriptive refers to research that is solely carried out based on the existing facts or phenomena that empirically exist in the speakers which in turn the role of language in the form of the portrayal of a language can be generated; the exposures are the way they are. [34] The descriptive analysis in this study is in the form qualitative approach known as qualitative descriptive. [34] Data collection technique applied in this study are listen and observe method. It is a method conducted through listening and observing the language use. In this regard, a researcher listens and observes the language usage contained in the song lyrics of "Nyo'o Hape" H. Dodi Mansyur https://www.youtube.com/watch?v=rm6gYUNxz8I and "Nyonyo'oh Dedy Suhendra https://www.youtube.com/watch?v=a0MESmYR01A which provide social criticism.

\subsection{Data Source}

Primary data refers to the first hand data gathered by researchers themselves, the data are always specific to the researchers need, as argued [34]. In this study, primary data are obtained from Youtube musics "Sundanese Songs" through observation. While secondary data means data collected by previous researchers. The sources are obtained from books, journal, and articles, these secondary data may or may not be specific on the researcher's need as described by Shiryaeva. [31]

\subsection{Data Collection}

The data that have been collected, such as: a) song's lyrics are classified into types of constative and performative utterancel b) identifying the title of the song; c) marking the text lyrics especially the sentence, phrases, words which contains the social criticism; d) then, they are identified based on their context and are classified into the song lyrics of Sundanese folksongs that were gathered.

\subsection{Method of Data Analysis}

The data that have been collected, first are classified into the types of constative and performative utterance. Then they are identified based on their context and are classified into verbal text. Austin's (1962) speech act theory is used in analyzing data verbal text. Yus's 
(2011) cyber-pragmatics theory is used to analyze virtual community. These two theories are assumed to be related to each other for the following reasons: a) in order to identify social criticism in the texts of Sundanese song in YouTube, we have analyzed the context, paying attention to evaluative words, negative or positive connotations of words, constative and performative utterance, and monitored articles for recurring concepts, ideas or notions with negative or positive assessments or meanings; b) employing the principles of semantic analysis, we have looked into such relations as synonymy, metaphorical and associative connections between words and meanings, studied representative features of words which eventually constituted the set of verbal means of social criticism. Awareness of a particular organization of the physical and social world together with pragmatics analysis.

\section{Result And Discussion}

\subsection{The Form and Meaning of Constative and Performative Utterance}

To respond to the question point (a) of this study, namely the form and meaning of constative utterance of the lyric that contains social criticism. Constative is a speech act that binds the speaker to the truth of what is said, or a constative as an utterance which states a fact that is true or false. It is affirming identifying, reporting, predicting. This type of speech act is also known as an assertive speech act. Speech that gives a reporting is constative. The data in the form of three Sundanese songs are used by the writer to get social criticism. The discussion starts from the sample data that shows constant speech. Based on the data obtained, the constative utterances, such as_Geus nyo'o hape panon tunduh 'often play cell phone sleepy eyes'; Ngadon sare 'then sleep'. This sentence reports facts that many Sundanese people play cellphones at night when it is time to fall asleep. It has an impact on poor sleep quality. Consequently, the social criticism contained in the song is analyzed as follows.

\subsubsection{Social Criticism of Cellphone Users}

Social criticism of cellphone users in this song is in the form of assertive speech acts. This speech act is a speech act in which the speaker expresses an utterance that shows the speaker's belief in what is very strong, so the speaker wants the interlocutor to form it. Some of the functions of assertive: stating, suggesting, refusing, pointing, defending, conveying, and saying, [22, pp. 105-106]. The following is an example of a Sundanese song lyric in an assertive speech act: a statement sentence. This statement sentence reports or provides information on a situation such as:

Table 1. Statement Sentences

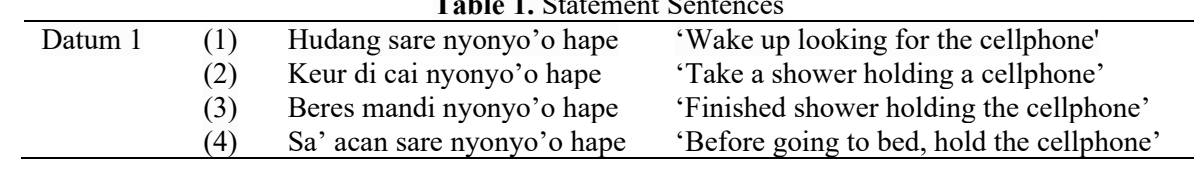

In datum 1, verse 1, lyrics 1-4 are analyzed from the SPEAKING aspect that consists of S (Setting): The setting/background in this verse, namely in the bedroom and the bathroom. The time setting occurs in the morning, afternoon, and evening to wake up, take a nap, and even sleep. P (Participants): The participants in this verse are the authors, singers, and Sundanese 
folk songs enthusiasts in general. E (Ends): The meaning of this verse as a whole describes the situation where the Sundanese people have used cellphones for various daily activities. A (Act Sequences): The form of speech in this song is identified as a monologue conversation. The form of the sentence is a declarative sentence. P (Participants): The participants in this verse are the authors, singers, and Sundanese folk songs enthusiasts in general. E (Ends): The meaning of this verse as a whole describes the situation where the Sundanese have used cellphones for various activities. A (Act Sequences): The lyrics in this song is identified as a monologue conversation. The sentence is a declarative sentence. A declarative sentence is defined as a sentence that contains a statement, serves to provide information without asking for a reply or reciprocity from others. K (Key): regarding the way or tone of speech, verse 1 in this song uses a relaxed, cheerful, but also confused tone. I (Instrumentalities): The language path used in this verse 1 is the spoken line, the tone of the song is sung with a variety of Sundanese regional languages. N (Norm): The norms contained in verse 1 show the aspect of a polite manner. The norms that are applied in Sundanese society, when it's time to sleep there is no need to use cellphones. It is a form of social criticism. The conversational genre in the lyrics of this song is a monologue.

The utterances in stanzas 1, lyrics 1-4 are Sundanese statement sentences containing social criticism related to the daily activities carried out by the Sundanese. In short, Sundanese can't get rid of their cellphones, as if they have entered the stage of cellphone addiction. The speaker, in this case the singer or songwriter, conveys information to the listener that they have used cellphones. Although, this information technology has had a positive impact on everyone such as being able to access information, knowledge, entertainment, increase insight, knowledge through cellphones, it can have a negative impact such as the ease of accessing pornography, violence, radicalism, and various other misleading information, namely hoaxes. The form of criticism that I want to convey is that cellphones have many functions, but cellphones also have many dangers to the human body.

\subsubsection{Social criticism of the Sundanese People Who Cook While Using a Cell Phone}

Table 2. Datum 2 and Datum 3

\begin{tabular}{|c|c|c|c|}
\hline Datum 2 & $(5)$ & Jol ka dapur nyonyo'o hape & 'Go to the kitchen hold the cell-phone' \\
\hline \multirow[t]{3}{*}{ Bait 2} & (6) & Bari nyangu nyonyo'o hape & 'Hold the cellphone while they cook' \\
\hline & (7) & Barang dahar nyonyo'o hape & 'Hold the cellphone while they eat' \\
\hline & $(8)$ & Sapo poe nyonyo'o hape & 'Hole the cellphone everyday' \\
\hline Datum 3 & (9) & $\begin{array}{l}\text { Kitu jeung kitu pegawean unggal } \\
\text { poe }\end{array}$ & 'This activity is done every day. \\
\hline \multirow[t]{3}{*}{ Bait 3} & $(10)$ & $\begin{array}{l}\text { Mun digeroan kadang-kadang } \\
\text { hare-hare }\end{array}$ & 'If advised, they get angry' \\
\hline & $(11)$ & Geus nyo'o hape panon tunduh & 'After using the cellphone they are sleepy \\
\hline & $(12)$ & $\begin{array}{l}\text { Pas hudung sare nu diteanganana } \\
\text { hape }\end{array}$ & $\begin{array}{l}\text { 'After waking up, they look for the } \\
\text { cellphones' }\end{array}$ \\
\hline
\end{tabular}

In datum 2-3, stanzas 2-3, the lyrics (5-12) are analyzed from the SPEAKING aspect which consists of S (Setting): The setting/background in this verse, namely in the kitchen, dining room, and family room. The time setting occurs in the morning, afternoon, evening, and night. Sundanese people cook food in the morning as breakfast time. After eating they do their daily activities. P (Participants): The participants in this verse are the authors, singers, and Sundanese folk songs enthusiasts in general. E (Ends): The meaning of this verse as a whole describes the real situation, that the Sundanese people have used cellphones for various 
daily activities. A (Act Sequences): The form of speech in this song is identified as a monologue conversation. The form of the sentence is a declarative sentence. Declarative sentence is defined as a sentence that contains a statement and serves to provide information without asking for a reply or reciprocity from others. K (Key): regarding the way or tone of speech, verse 1 in this song uses a relaxed, cheerful, but also confused tone. I (Instrumentalities): The language path used in this verse 1 is the spoken line, the tone of the song is sung with a variety of Sundanese regional languages. N (Norm): The norms contained in verse 1 show the information given by the songwriter to the listener in a polite manner. Social criticism on datum 2 cellphones is a something that they cannot live without their cellphone. In fact, even when cooking, HP is still carried everywhere. For example, just replying to messages from friends while cooking. In fact, there are many incidents where cellphones explode because women were cooking in the kitchen, then without realizing it they put their cellphones near the stove, then the cellphone exploded.

In datum 2-3, stanzas 2-3, the lyrics (5-12) are analyzed from the SPEAKING aspect which consists of S (Setting): The setting/background in this verse, namely in the kitchen, dining room, and family room. The time setting occurs in the morning, afternoon, evening, and night. Sundanese people cook food in the morning as breakfast time. Lunch time. After eating they do the activities of daily life. P (Participants): The participants in this verse are the authors, singers, and Sundanese folk songs enthusiasts in general. E (Ends): The meaning of this verse as a whole describes the real situation, that the Sundanese people have used cellphones for various daily activities. A (Act Sequences): The form of speech in this song is identified as a monologue conversation. The form of the sentence is a declarative sentence. Declarative sentence is defined as a sentence that contains a statement and serves to provide information without asking for a reply or reciprocity from others. K (Key): regarding the way or tone of speech, verse 1 in this song uses a relaxed, cheerful, but also confused tone. I (Instrumentalities): The language path used in this verse 1 is the spoken line, the tone of the song is sung with a variety of Sundanese regional languages. N (Norm): The norms contained in verse 1 show the information given by the songwriter to the listener in a polite manner. Social criticism on datum 2 cellphones is a tool that they cannot breathe without their cellphone. In fact, even when cooking, HP is still carried everywhere then without realizing it they e. For example, just replying to messages from friends while cooking. In fact, there are many incidents where cellphones explode because women who were cooking in the kitchen and without realizing it they put their cellphones near the stove, then the cellphone exploded.

Table 3. Datum 4

\begin{tabular}{llll}
\hline Datum 4 & $(13)$ & Bisi urang jadi teu eling & 'make someone forget' \\
Bait 4 & $(14)$ & Poho dahar awak cungkrig & 'forget to eat' \\
& $(15)$ & Nu di imah jadina rungsing & 'dizzy person' \\
& $(16)$ & Euweh hape da moal paeh & 'can't die without \\
\hline
\end{tabular}

In datum 4, stanzas, lyrics (13-16) are analyzed from the SPEAKING aspect which consists of S (Setting): The setting/background in this verse of the song, namely in the home environment. Timelines occur every day. P (Participants): The participants in this verse are the authors, singers, and Sundanese folk songs enthusiasts in general. E (Ends): The point of showing this verse is the ease of technology presented on a cellphone, making it difficult for people to take it off their hands. Although there are positive effects, there are also negative effects from using cellphones, namely people often forget themselves, for example forgetting to eat, the impact is that the body becomes thin, sick and makes. A (Act Sequences): The 
form of speech in this song is identified as a monologue conversation. The form of the sentence is a declarative sentence. Declarative sentence is defined as a sentence that contains a statement and serves to provide information without asking for a reply or reciprocity from others. K (Key): regarding the way or tone of speech, verse 1 in this song uses a relaxed, cheerful, but also confused tone. I (Instrumentalities): The language path used in this verse 1 is the spoken line, the tone of the song is sung with a variety of Sundanese regional languages. $\mathrm{N}$ (Norm): The norms contained in verse 1 show the information given by the songwriter to the listener in a polite manner. The norms that apply in Sundanese society, when eating is always ngariung. Ngariung is a hereditary tradition carried out by the Sundanese. Ngariung tradition is an activity to eat together by sharing experiences with each other. Ngariung itself is often done by people while discussing and sharing opinions. However, at this time, the atmosphere has changed, they are singing together but no longer discussing and sharing opinions. They already have their own busy life communicating with friends who are far away from what is in front of their eyes digging information from cellphones. The results of the analysis above show that, the social criticism proposed is in the form of predictive speech, the speaker conveys speech to predict the negative effects of physical and spiritual health cellphones will be damaged. This is to influence the speech partner to believe in the speech. Predictive speech has several functions, namely predicting and predicting something will happen.

To respond to the question point (b) this study explains the motives of songwriters conveying social criticism through Sundanese folk songs. Motives refer to all the motives reason impulses in humans that cause them to do something. The motive in the song "Nyonyo'oh Hape" is in the form of encouragement which is reflected through the pattern of constative sentences, namely: Sa' acan sare nyonyo'o hape 'Before going to bed using the cellphone' and predictive sentences nyonyo'o hape bisi urang jadi teu eling 'People who often use cell phones will make them forgetful.' This sentence contains the meaning of social motive. The social motive is conveyed in that sentence because it knows the fact that the Sundanese:

1. enjoy to interact with other people over the phone;

2. develop Sundanese culture and civilization over time so as to evolve according to the development of digital industrial technology;

3. are concerned about the high cost of cell phones;

4. especially Sundanese song-writer's are aware that music can be used as a tool to express social experiences, feelings, beauty, and criticism about a social condition that is conveyed in a friendly manner.

5. Social-interaction in the era of information and communication technology development; Close interaction between communication devices in the form of cellphones and the community. For example, interactions in virtual communication groups such as WhatsApp, Telegram, Instagram, and Twitter. The situations cause people to hold their cell phones every time;

6. Sundanese of virtual-society refers to a group of Sundanese internet users who form a network of personal relationships. The Sundanese community has lived in two worlds of life, namely real-life and cyber-community;

7. Both individually and in groups, are more interested in communicating in cyberspace;

8. Consider that the cell phone is a very personalized one. Sundanese people do not need public space or physical contact as a driving force for interaction, but the interaction is now more towards the face to the screen using mobile phones than face to face;

9. Knowledge development tools: virtual groups have been used as a medium for efficient and effective information retrieval; 
10. Using virtual communities to build personal relationships and enjoy entertainment.

Based on, the explanation above shows that songwriters or singers have a strategic role in conveying criticism. Sundanese songwriters and singers do not only act as models for creating ideas. However, they are agents in transforming social values and norms that prevail among the Sundanese people. Sundanese song identification is an effective means of conveying criticism. The delivery of the criticism is not separated from the songwriter having a motive as the basis of the driving force from within himself to carry out activities to create songs to achieve a common goal. It has been accepted by Sundanese society. In brief, the motive that songwriter deliver, such as: a) informative motives refer to everything related to the desire to meet the need for knowledge; b) party motives refer to things related to getting pleasure; c) personal integration motives are motives that arise from the desire to strengthen status, credibility, self-confidence; d) social integrative motives are intended to strengthen social contacts by interacting with family, friends, and other people; e) escape motive refers to behavior to escape from routine, boredom, or when they are alone; f) making a positive behavior change.

Francisco Yus's virtual community concept is used to generate the motive of social media users in conveying social criticism through folk songs. Francisco Yus said that in a virtual community, virtual communication is formed. This virtual communication takes place using the internet network. This network is the main intermediary tool that is the link between the communicator and the communicant. Virtual communication refers to one of the channels for distributing messages through mass media whose distribution is through the internet network. The presentation is broad, up-to-date (latest), interactive, and two-way communication. [15] Indonesians have started using the internet to satisfy their curiosity and to obtain information. Virtual communication itself is part of the innovations that continue to develop in social media. The internet aims to make it easier for humans to interact. They can seek knowledge and economic needs where users can enjoy. It is no time or region limits. According to Yus, virtual communication that is developing in human life allows for the presence of a new environment, which he calls a "virtual environment" [15]. Using the concept above, in the song "Nyonyo'oh hape" there are basic concepts that are part of virtual communication including:

\section{a) Cyberspace}

Cyberspace is an electronic medium in the telephone network that is widely used for online one-way and reciprocal communication purposes. This is evidenced in the lyrics of Co'o deui, co'o deui co'o deui, 'press the cellphone toots again, press the cellphone toots again'; Bapana nyo'o hape, 'father presses cellphone, budakna nyo'o hape, 'his son presses cellphone, Indungna nyo'o hape, 'mother presses cell phone' aya naon dina hape 'what's in the phonecell'. The lyrics of this song indicate the need for online communication of the Sundanese people.

\section{b) Virtual community}

Virtual communities are emerging communities in the world of electronic communication. This is shown through chat rooms in the form of WhatsApp, telegram, twitter, e-mail are new examples of places that can be used by the community to communicate with each other. The song lyrics are such as: Bapana nyo'oh hape, 'the father uses phone-cell, budakna nyo'o hape, 
'the children use phone-cell, indungnya nyo'o hape, 'the mother uses phone-cell,' aya naon dina hape 'what are they in the phone-cell'.

\section{c) Text}

Through text, the author can send news to readers. Readers can quickly find out more about topics or words, documents, or user-submitted text using links about information related to that text. For example: Detik menit hape jeung hape 'every second and minute using a phone-cell' This lyric is interpreted as Sundanese people have cognitive needs. Cognitive needs are needs related to information, knowledge, and understanding of the environment. They try to find much information that varies from the mass media. They use it so that their needs have been met to pass the time-limit.

\section{d) Photo}

The photo is used as a self-representation of the account owner. Photos of Sundanese singers are considered to represent the image or identity of the owner or community members who can send various photos.

\section{e) Multi-media}

Multi-media is a communication system that offers a mix of text, graphics, sound, video, and animation. Using this multi-media, the songwriter sends his social critique. For example in the lyric beja eta, beja iyeu dina hape, 'give much information via phone-cell', whatsApp group jeung Instagram tos ilahar, 'WhatsApp and Instagram have become a-major need' buka youtube jeung game online mobil lecen, 'opening Youtube and online games are already good' In short, in terms of using the concept of a virtual community in the lyrics of the Sundanese song entitled Nyo'o hape, there are elements of virtual communication that are familiar to the Sundanese people in order to facilitate communication and gain knowledge.

\section{Conclusion}

Based on the results of the analysis of speech events in Sundanese songs, the conclusion has drawn, such as follow: To respond to the question point (a) the form and meaning of constative and performative utterance of the lyrics that contain social criticism, this study describes the songwriter conveys criticism using constative meaning statements in speech-act such as a report, inform, and state. The sentences contain social values, such as satire 12 (twelve) lyrics. In addition, the concept of performative sentences by Austin (1962) is used to analyze lyrics that impact create actions and physical behavior patterns. They are 10 (eight) cognitive lyrics and psychical 15 (six) lyrics, as well as social interactions 11 (eleven) lyrics. The songwriter expresses a positive criticism of the behavior of the Sundanese people in the information technology era. This song lyric analysis also uses the 8 (eight) conditions to become a speech event. In this episode, there are 48 total lyrics. The main topic is the problem of using phone-cell in all daily activities that cannot be abandoned by the Sundanese people. In Settings, there are five place settings, namely bedroom, bathroom, kitchen, dining room, and workplace. In participants, it refers to the activities of the Sundanese people who 
are actively using cellphones. The purpose of showing this song is to do social criticism that focuses on behavior, not on the Sundanese.

To respond to the question point (b) this study explains the motives of songwriters conveying social criticism through Sundanese folk songs. By using SPEAKING analysis to this song lyric, it can be concluded that the motive of the song are: a) informative motives refer to everything related to the desire to meet the need for knowledge; b) Entertainment motives refer to things related to getting pleasure; c) personal integration motives are motives that arise from the desire to strengthen status, credibility, self-confidence; d) social integrative motives are intended to strengthen social contacts by interacting with family, friends, and other people; e) escape motive refers to behavior to escape from routine, boredom, or when they are alone; f) making a positive behavior change. Using the cyber-pragmatics perspective, there are 7 (seven) contexts that cause social criticism, namely: 1) the influence of foreign culture, 2) social distance, 3) social status, 4) social interaction, 5) using internet-connected, 6) gadgets, and 7) vertical relationships between individuals.

The writers would like to suggest to the other researcher to explore the study of Sundanese as local language speech to act passionately in different context, as focuses on poetry aspect, novel, short story by using sociolinguistics point of view, such as the addition of genetic structuralism research views literary works from two angles, namely intrinsic and extrinsic. Furthermore, the other researcher can choose another genre of the expression of the author's character and feelings), and opposes the assumption that literary works are a medium of communication between the author and the reader. They can use other sources instead of acquiring the data from social-media, such as Telegram or Twitter verbal text in social media. These diversities can broaden more perspectives on genetics-structuralism, linguistics and pragmatics capability to decide on research in the university.

\section{Acknowledgements}

I would like to express my special thanks of gratitude to Translation Department and to Bahtera conference international committee as well as our Sundanese informant who gave me the golden opportunity to do this wonderful project on the topic Sundanese Songs which also helped me in doing a lot of Sundanese Research and I came to know about so many new things. I am really thankful to them.

\section{References}

[1] J. Maknuni, "Pengaruh Media Belajar Smartphone Terhadap Belajar Siswa Di Era Pandemi Covid-19 (The Influence of Smartphone Learning Media on Student Learning in The Era Pandemi Covid-19)," Indones. Educ. Adm. Leadersh. J., vol. 02, no. 02, pp. 94-106, 2020, [Online]. Available: https://onlinejournal.unja.ac.id/IDEAL/article/view/10465.

[2] N. S. Parhusip, "Hukum Pidana Dan Kaitannya Dengan Penggunaan Media Sosial," To-Ra, vol. 1, no. 1, p. 67, 2015, doi: 10.33541/tora.v1il.1097.

[3] D. K. S. Ricadona Priyanti Lim, Daru Purnomo, "Pengaruh Pengguna Instagram Terhadap Kesehatan Mental," Komuniti J. Komun. dan Teknol. Inf., vol. 13, no. 1, pp. 47-66, 2021, [Online]. Available: https://journals.ums.ac.id/index.php/komuniti/article/view/13757/6599. 
[4] A. Abidah, H. N. Hidaayatullaah, R. M. Simamora, D. Fehabutar, and L. Mutakinati, "The Impact of Covid-19 to Indonesian Education and Its Relation to the Philosophy of 'Merdeka Belajar,"' Stud. Philos. Sci. Educ., vol. 1, no. 1, pp. 38-49, 2020, doi: 10.46627/sipose.v1i1.9.

[5] S. A. Madya and Abdurahman, "Online Learning Implementation in the Covid-19 Pandemic," Proc. Ninth Int. Conf. Lang. Arts (ICLA 2020), vol. 539, no. Icla 2020, pp. 26-31, 2021, doi: 10.2991/assehr.k.210325.005.

[6] M. M. Zalat, M. S. Hamed, and S. A. Bolbol, "The experiences, challenges, and acceptance of e-learning as a tool for teaching during the COVID-19 pandemic among university medical staff," PLoS One, vol. 16, no. 3 March, pp. 1-12, 2021, doi: 10.1371/journal.pone.0248758.

[7] A. M. Pratama, "Pengguna Internet Indonesia hingga Kuartal II 2020 Capai 196,7 Juta Orang." Kompas.com, Jakarta, 2020.

[8] A. M. Vinka and N. Michele, "Pengaruh Teknologi Internet Terhadap Pengetahuan Masyarakat Jakarta Seputar Informasi Vaksinasi Covid-19," J. Teknol. Inf. Dan Komun., vol. 8, no. 1, pp. 1-13, 2021, [Online]. Available: https://www.jurnal.plb.ac.id.

[9] M. T. R. Eni Susanti, Septiawan Ardiputra, "Peran Media Sosial dan 'TEMAN AHOK' Dalam Mendorong Perubahan Sosial,” Media Bina Ilm., vol. 15, no. 7, pp. 4897-4906, 2021, [Online]. Available: http://ejurnal.binawakya.or.id/index.php/MBI.

[10] M. F. and M. M. Arfanda, "Kritik Sosial Pada Lirik Lagu Karya Feast," Nusa, vol. Vol. 15 No, no. Literature, pp. 199-213, 2020, [Online]. Available: https://ejournal.undip.ac.id/index.php/nusa/article/view/32017/17747.

[11] M. Marwadianto, "Hak Atas Kebebasan Berpendapat dan Berekspresi," J. HAM, vol. 11, no. 1, pp. 1-4, 2020, [Online]. Available: https:/ejournal.balitbangham.go.id/index.php/ham/article/view/976/pdf.

[12] L. Nasution, "Hak Kebebasan Berpendapat dan Berekspresi dalam Ruang Publik di Era Digital," 'Adalah, vol. 4, no. 3, pp. 37-48, 2020, doi: 10.15408/adalah.v4i3.16200.

[13] P. G. Notanubun, "Tinjauan Yuridis Terhadap Kebebasan Berbicara Dalam Ketentuan Pasal 27 Ayat 3 UU Nomor 11 Tahun 2008 Tentang ITE Dalam Hubungan Dengan Pasal 28 UUD 1945," J. Ilmu Huk., vol. 12, no. 2, p. 112, 2014, [Online]. Available: https://media.neliti.com/media/publications/240089-tinjauan-yuridis-terhadapkebebasan-berb-c58d5036.pdf.

[14] V. Vosahlik, "The Relationship between Poetry and Music Lyrics," University of Bohemia, 2016.

[15] F. Yus, Cyberpragmatics Internet-mediated communication in context, First. Amsterdam: John Benjamins, 2011.

[16] M. Perano, G. L. Casali, Y. Liu, and T. Abbate, "Professional reviews as service: A mix method approach to assess the value of recommender systems in the entertainment industry," Technol. Forecast. Soc. Change, vol. 169, no. 132, p. 120800, 2021, doi: 10.1016/j.techfore.2021.120800.

[17] K. Kryston and A. Eden, "I Like What You Like: Social Norms and Media Enjoyment," Mass Commun. Soc., vol. 00, no. 00, pp. 1-23, 2021, doi: 10.1080/15205436.2021.1934703.

[18] S. Park, K. Kryston, A. Eden, S. Park, K. Kryston, and A. Eden, "Social Norms and Social Identity Explain the Selection and Anticipated Enjoyment of In-Group Versus Out-Group Films,” 10.1037/ppm0000331, pp. 1-12, 2020, doi: 10.1037/ppm0000331.

[19] M. Kopytowska, "NARRATING HOSTILITY, CHALLENGING HOSTILE 
NARRATIVES," Pragmatics, vol. 4, no. 1, pp. 1-24, 2018, doi: https://doi.org/10.1515/lpp-2018-0001.

[20] Indra Ridwan, "The Art of The Arranger in Pop Sunda , Sundanese Popular Music of West Java , Indonesia,” University of Pittsburgh, 2014.

[21] W. Susanti and E. Nurmayani, "Kritik Sosial dan Kemanusiaan dalam Lirik Lagu Karya Iwan Fals," SeBaSa J. Pendidik. Bhs. dan Sastra Indones., vol. 3, no. 1, pp. 1-8, 2020, [Online]. Available: https:/ejournal.hamzanwadi.ac.id/index.php/sbs/article/view/2172.

[22] G. Leech, Principles of Pragmatics. London: Routledge Taylor and Francis Group, 2014.

[23] E. Figueroa, "Dell Hymes and the Ethnography of Communication-Sociolinguistic Relativism," Socioling. Metatheory, pp. 31-68, 1994, doi: 10.1016/b978-0-08-0423999.50008-5.

[24] J. . Austin, How to Do Things With Words, First edit. Oxford: Oxford University Press, 1962.

[25] G. of Yule, The Study of Language, Fourth. Cambridge: Cambrdige University Press, 2010.

[26] A. Aryanto, B. Sudardi, A. Purwasito, and A. Wakit, "Social Criticism in the Text Scripture of Dharmasonya," KOMUNITAS Int. J. Indones. Soc. Cult., vol. 9, no. 1, pp. 70-80, 2017, doi: 10.15294/komunitas.v9i1.8340.

[27] H. N. H. . Hasibuan, A. Effendi, and M. Margana, "Social Criticism in Konspirasi Alam Semesta Novel By Fiersa Besari,” Sosiohumaniora, vol. 23, no. 2, p. 218, 2021, doi: 10.24198/sosiohumaniora.v23i2.32132.

[28] M. Osman and N. H. Jalaluddin, "Social Criticism Via Myths and Metaphors: An Adhoc Analysis," Procedia - Soc. Behav. Sci., vol. 118, pp. 265-272, 2014, doi: 10.1016/j.sbspro.2014.02.036.

[29] K. Dougan, "Music, Youtube, and Academic Libraries," Music Libr. Assoc. Stable, vol. 72, no. 3, pp. 491-508, 2016.

[30] K. Dougan, "'YouTube has changed everything'? Music faculty, librarians, and their use and perceptions of YouTube," Coll. Res. Libr., vol. 75, no. 4, pp. 575-589, 2014, doi: $10.5860 / \mathrm{crl} .75 .4 .575$.

[31] T. A. Shiryaeva, A. A. Arakelova, E. V. Tikhonova, and N. M. Mekeko, "Anti-, Non-, and Dis-: the linguistics of negative meanings about youtube," Heliyon, vol. 6, no. 12, p. e05763, 2020, doi: 10.1016/j.heliyon.2020.e05763.

[32] K. M. Higgins, "Connecting Music to Ethics," Coll. Music Symp., vol. 58, no. 3, pp. 120, 2018, doi: 10.18177/sym.2018.58.sr.11411.

[33] P. Astor, "The poetry of rock: Song lyrics are not poems but the words still matter; another look at Richard Goldstein's collection of rock lyrics," Pop. Music, vol. 29, no. 1, pp. 143-148, 2010, doi: 10.1017/S0261143009990055.

[34] J. W. Creswell, Research Design Qualitative Quantitative and Mixed Methods Approaches, Third Edit., vol. 8. California: SAGE Publication Ltd, 2009. 